\title{
An Approach of D-STATCOM in Single Phase System with Power Quality Improvement
}

\author{
Ms. Akansha Chourasia \\ Assistant Professor (Department of Electrical Engineering, PIEMR, Indore)
}

\begin{abstract}
The paper describes the design of D-STATCOM in single phase for voltage interruption mitigation of fault in an unbalance system. Speed of response is higher than static var compensator (SVC) and harmonic emission is less than SVC that is why D-STATCOM is used in place of static var compensator. It validates the performance of D-STATCOM for improving power quality and harmonics. It provides a guide for utilities to have an appropriate choice of FACTS devices for enhancing stability. The work proposes a two pulse STATCOM configurations in which voltage source inverter uses IGBT as a switching device have been simulated using MATLAB/SIMULINK. Accordingly, simulation is first carried out to illustrate use of D-STATCOM in mitigating voltage interruption in single phase. The scope of the paper is to explore the D-STATCOM in single phase. Normally, D-STATCOM is not used in single phase, so an attempt has been made to introduce DSTATCOM in single phase load or household applications.

Simulation results of $3 \mathrm{KVAR}$ D-STATCOM validate that integrated D-STATCOM with $230 \mathrm{~V}, 91 \mu \mathrm{F}$ capacitor is suited for single phase system with voltage interruption mitigation capacity.
\end{abstract}

Keywords - FACTS, voltage interruption, D-STATCOM, load compensation, VS

\section{INTRODUCTION}

At present world, electricity demand is undergoing a profound transformation. Today various power quality and reliability issues are faced by us to maintain security of the whole power system. Installing new transmission lines is a costlier process. The ever changing atmospheric condition has an impact on the transmission network and load. Available power production does not meet the growing load demand and better power quality. So FACTS device is an alternative way to enhance power transmission capability and quality. Last few decades ago synchronous condensers are used for this purpose but it has some limitations which are overcome by the use of FACTS devices. The reasons are ofcourse lower investment cost, no rotating parts, symmetrical lead-lag capacity, no resonance problem, no loss of synchronism; interfacing is provided and requires less space in power system network. [5]

Now a days there are many power related issues and voltage interruption is the one among them and is considered the most critical power quality problem. By definition, voltage interruption is defined as "momentary interruption causes a complete loss of voltage either for a short or long duration". Due to sudden change in load or disturbances in the utility system, voltage interruption takes place. [10] Faults occur may be either single phase or multiphase which results in voltage fluctuation issues at the end. [3] Real power flow in a lossless power system is-

$\mathrm{P}=\frac{\mathrm{V} 1 \mathrm{~V} 2 \sin \alpha}{\mathrm{X}}$

Where, $V_{1}, V_{2}$ are the bus voltage magnitude at sending end and receiving end respectively and $\alpha$ is the angle between voltages $\mathrm{V}_{1}$ and $\mathrm{V}_{2}$. $\mathrm{X}$ is the reactance of transmission line. [4]

Capacitor is used for compensation purpose from last few years but capacitor has following drawbacks-

- The reactive power supplied by the shunt capacitor is directly proportional to the bus voltage.

- Precise and rapid control of voltage is not possible because it is a discrete device. [6]

Due to above drawbacks, a great opportunity to regulate transmission of $\mathrm{AC}$ is offered by FACTS controller by balancing the power flow in a designated transmission line almost instantaneously. FACTS technology is a collection of controllers not a single controller. According to the definition of FACTS that "an AC transmission system incorporating power electronic based and other static controller to enhance controllability and increasing power transfer capability." [1] 


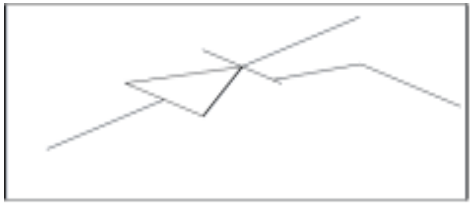

Fig. 1 Symbol of FACTS Device

The main aim of utilizing FACTS controllers are as follows-

- It manages the flow of power in a system.

- Transmission lines can be loaded nearer to their thermal limits without damage.

- Prevent contingency followed by an outage.

- Damp out the oscillations which limits the use of line capability.

\section{STATIC SYNCHRONOUS COMPENSATOR (STATCOM)}

Key device of FACTS controller is

STATCOM. Controlled reactive power is provided by STATCOM. It is also known as advanced SVC. It is shunt connected FACTS device. Shunt connected controllable reactors as connected in SVC are replaced by voltage source converter in STATCOM. To deliver constant DC at the input of inverter, an energy source is connected. It provides compensated var by either providing or consuming var from the system.

\section{A. PRINCIPLE}

The principle of STATCOM is like a synchronous condenser or compensator that it balances the flow of reactive power and voltage of the system to the desired value in which it is connected but faster than it. System voltage changes linearly with the DC voltage across the capacitor.

\section{B. STRUCTURE}

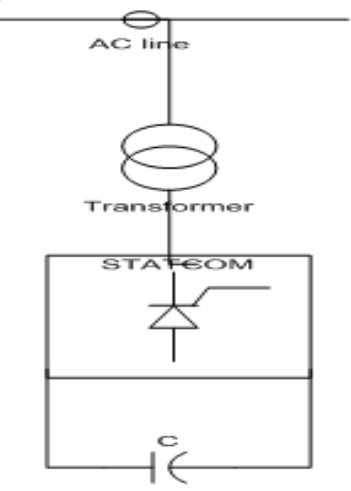

Fig. 2 STATCOM

Brief STATCOM configuration is described below-

a) Voltage source inverter

b) Coupling transformer

c) Controller
Coupling Transformer - The leakage inductance of it work as a coupling reactor. Its leakage inductance act as a filter which filter out the current harmonic components produced by output voltage of the voltage source converter. Its compensation does not depend on the coupling voltage.

Controller - It generates firing pulses for the converter. It performs a feedback control. Here it is pulse generator block in simulink. Controller develops synchronism between output voltages of the converter with the system voltage. The controller has two terminals one is reference and other to provide the gate pulses to the converter.

Capacitor- The voltage across capacitor does not change instantaneously; therefore STATCOM gives the desired response. Constant DC voltage is provided by a capacitor to the inverter. [7]

\section{OPERATION}

The STATCOM is connected to the power system at sending or middle or receiving end of the transmission line where the power quality is a matter of concern. The supply to voltage source inverter is given by capacitor $\mathrm{C}$ which generates synchronized output voltages. Following are the modes of operation of STATCOM-

$\mathrm{U}_{\text {ref }}$ - Desired voltage across STATCOM, which is set manually

- STATCOM does not exchange any reactive power with the system when magnitudes of output voltage of both are same means no reactive current flows in the system.

- STATCOM provides leading reactive power to the system that is capacitive var when voltage sag or interruption takes place and reactive current flows from device to system through transformer reactance.

- STATCOM consumes lagging reactive power that is inductive var when voltage swell occurs and reactive current flows from system to device through transformer reactance.

Amount of reactive power generated or absorbed depending upon the firing angle of the converter.

\section{DESIGN OF D-STATCOM}

\section{A. Inverter Design}

Inverters are used to convert fixed DC input quantity to variable AC output quantity. In this work a single phase two pulse voltage source inverter has been developed. The capacitor is charged by a battery which is used as energy storage here. Phase delay between devices used is $30^{\circ}$. 


\section{B. Capacitor Sizing}

It depends on the fault current. The value of $\mathrm{V}_{\mathrm{Cmax}}$ is the present upper limit of $\mathrm{C}_{\mathrm{dc}}$, and is two or three times the $V_{d c}$. [3] The following equation is used to calculate $\mathrm{C}_{\mathrm{dc}}$ for single phase -

$$
\mathrm{C}_{\mathrm{dc}}=\frac{\mathrm{Vs} . \Delta \mathrm{I} \cdot \mathrm{T}}{\mathrm{VCmax} 2-\mathrm{Vdc} 2}
$$

Where,

$\mathrm{V}_{\mathrm{s}}=$ Peak voltage

$\mathrm{I}_{\mathrm{L}}=$ Load current

$\mathrm{T}=$ Time Period

$\mathrm{V}_{\mathrm{Cmax}}=$ pre set voltage of energy storage $\mathrm{C}$

$\mathrm{V}_{\mathrm{dc}}=$ Voltage across capacitor $\mathrm{C}$

\section{ADVANTAGES OF STATCOM OVER SVC}

- Reactive Component - lesser than SVC

- Better transient response

- Interfacing - It can be interfaced with real power sources such as battery, fuel cell, super conducting magnetic energy storage (SMES).

- Characteristics - It is superior to SVC because as reactive current can be maintained constant in STATCOM whereas in SVC it linearly increases with voltage.

- Space - It requires less space as bulky passive components such as reactors are eliminated. [2] [9]

\section{INDIAN SCENARIO}

TABLE 1. Proposed STATCOM projects in India

\begin{tabular}{|l|l|l|l|l|}
\hline State & $\begin{array}{l}\text { Location } \\
\text { S/s }\end{array}$ & $\begin{array}{l}\text { v/g } \\
\text { level } \\
(\mathbf{K V})\end{array}$ & $\begin{array}{l}\text { MVA } \\
\text { R } \\
\text { Ratin } \\
\text { g }\end{array}$ & $\begin{array}{l}\text { Estima } \\
\text { ted } \\
\text { Cost } \\
(\mathbf{C r} .)\end{array}$ \\
\hline J \& K & $\begin{array}{l}\text { Udhampur } \\
\text {,Budgam }\end{array}$ & 220 & $\begin{array}{l}(+) 125 \\
/(-) 25\end{array}$ & $57.5 * 2$ \\
\hline Rajasthan & Tinwari & 220 & $\begin{array}{l}(+) 50 / \\
(-) 100\end{array}$ & 57.5 \\
\hline $\begin{array}{l}\text { Andhra } \\
\text { Pradesh }\end{array}$ & $\begin{array}{l}\text { Urvakond } \\
\text { a }\end{array}$ & 220 & $\begin{array}{l}(+) 100 \\
/(-) 100\end{array}$ & 57.5 \\
\hline Karnataka & $\begin{array}{l}\text { Chitradurg } \\
\text { a }\end{array}$ & 220 & $\begin{array}{l}(+) 50 / \\
(-) 100\end{array}$ & 57.5 \\
\hline Gujarat & $\begin{array}{l}\text { Radhanpu } \\
\text { r }\end{array}$ & 220 & $\begin{array}{l}(+) 50 / \\
(-) 100\end{array}$ & 57.5 \\
\hline
\end{tabular}

The total estimated cost of STATCOM project is Rs.704 Crores and it will plan located in different parts of India from north to south. Its cost as well as rating in comparison with SVC is less. The above details are for three phase. In the present work an attempt has been done for single phase utilities. [8]

\section{SIMULATION RESULTS AND DISCUSSION}

The simulation of D-STATCOM followed by voltage interruption from sim power system library. Fig.3 and fig.4 shows the simulink model of single phase system without D-STATCOM and with DSTATCOM respectively. Following parameters are used -

Table 2: System Parameters

\begin{tabular}{|l|l|}
\hline Supply voltage & $230 \mathrm{~V}$ \\
\hline Source impedance & $1 \Omega, 1 \mathrm{mH}$ \\
\hline Line impedance & $0.1 \Omega, 1 \mathrm{mH}$ \\
\hline Load impedance & $30 \Omega, 2 \mathrm{mH}$ \\
\hline
\end{tabular}

The percentage of sag or interruption is calculated as-

$$
\begin{aligned}
& \text { Sag }(\%)=\frac{\text { Vpre }- \text { Vpost }}{\text { Vpre }} * 100 \\
& \text { Sag }=\frac{325-0}{325} * 100 \\
& \text { Sag }=100 \%
\end{aligned}
$$

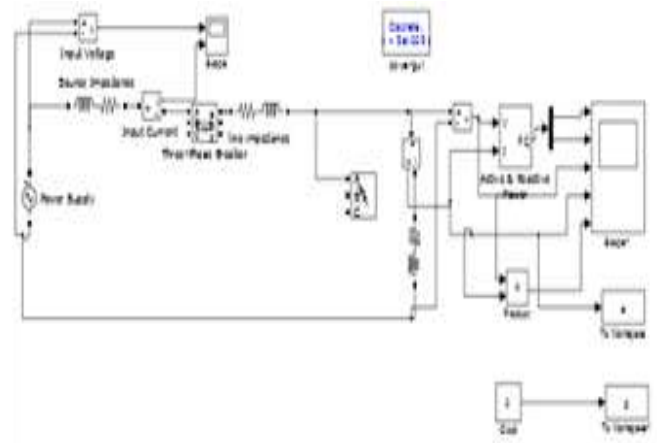

Fig. 3 Simulation of system without D-STATCOM

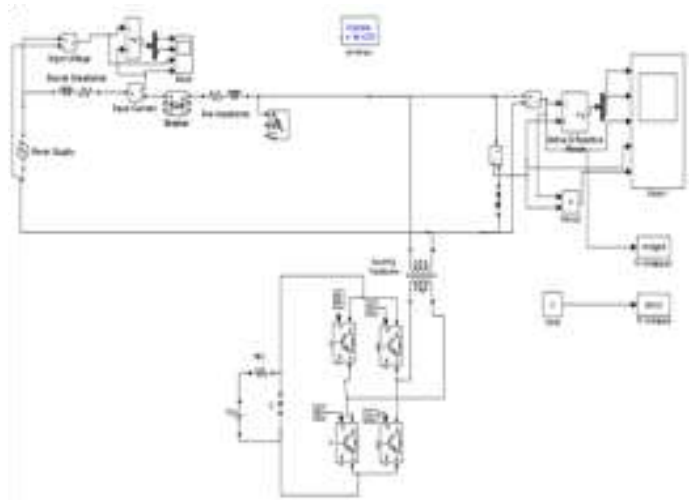

Fig. 4 Simulation of system with D-STATCOM

It is observed from the results in figure 6 that the load current $\mathrm{I}_{\mathrm{rms}}$ changes from 0 to $10 \mathrm{amp}$ and the load voltage (rms) dropped from 230 to $0 \mathrm{~V}$. From these the value of $\mathrm{C}_{\mathrm{dc}}$ is determined as follows- 
$\mathrm{C}_{\mathrm{dc}}=\frac{325 \times 10 \times 20}{1000 \times\left(1000^{2}-550^{2}\right)}$

$\mathrm{C}_{\mathrm{dc}}=93 \mu \mathrm{F}$

Where, $\Delta \mathrm{I}=10 \mathrm{amp}$

$$
\begin{aligned}
& \mathrm{T}=20 \mathrm{~ms} \\
& \mathrm{~V}_{\mathrm{Cmax}}=1000 \mathrm{~V} \\
& \mathrm{~V}_{\mathrm{dc}}=550 \mathrm{~V}
\end{aligned}
$$

The VAR rating of the D-STATCOM when $\mathrm{C}_{\mathrm{dc}}=$ $93 \mu \mathrm{F}$ is calculated as -
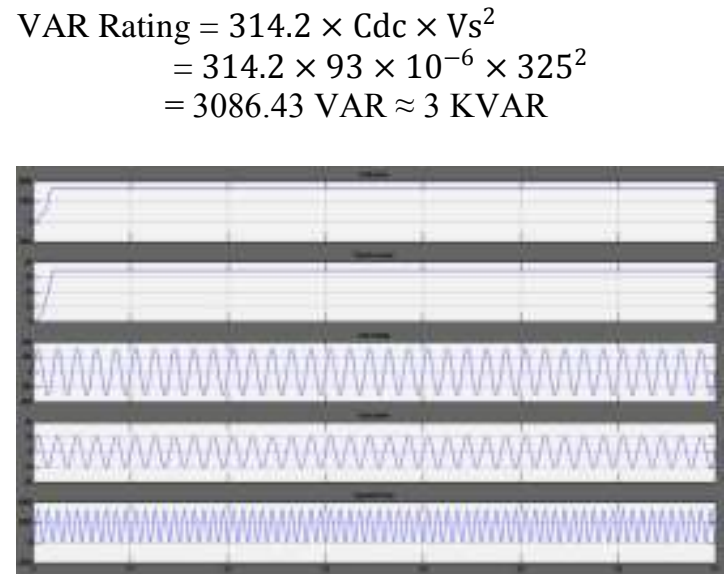

Fig.5 Real, Reactive power, Load voltage, Load current, Apparent power during normal condition

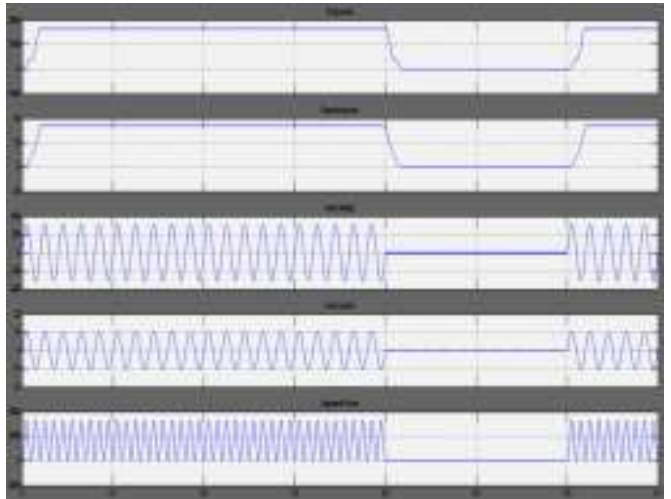

Fig.6 Real, Reactive power, Load voltage, Load current, Apparent power during voltage interruption

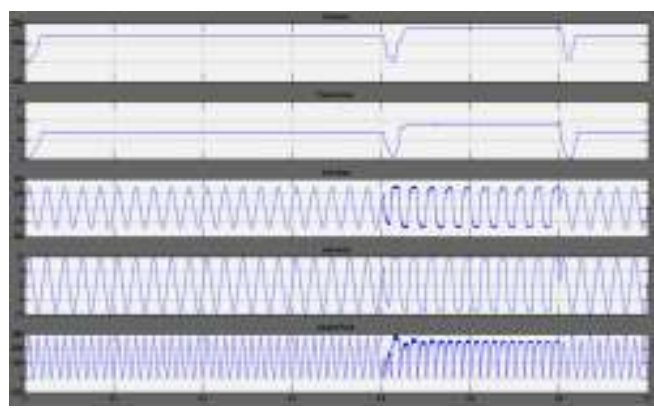

Fig.7 Real, Reactive power, Load voltage, Load current, Apparent power during D-STATCOM operation
Fig. 5 shows the normal operation of the AC system . Fig.6. shows single line to ground fault and the duration of voltage interruption is from 0.4 to 0.6 seconds. Here the fault resistance is $0.001 \mathrm{ohm}$ and the ground resistance is $0.001 \mathrm{ohm}$. In fig. $7 \mathrm{D}$ STATCOM become active, supplies reactive power to the AC system. Due to charging and discharging of capacitor connected across the inveter, spikes are observed at the starting and end points of voltage interruption.

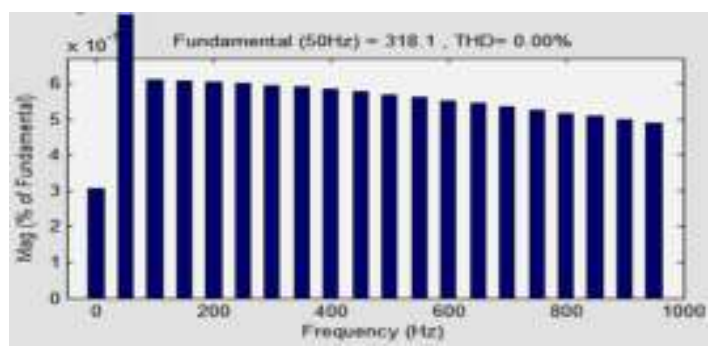

Fig. 8 Total harmonic distortion under normal condition

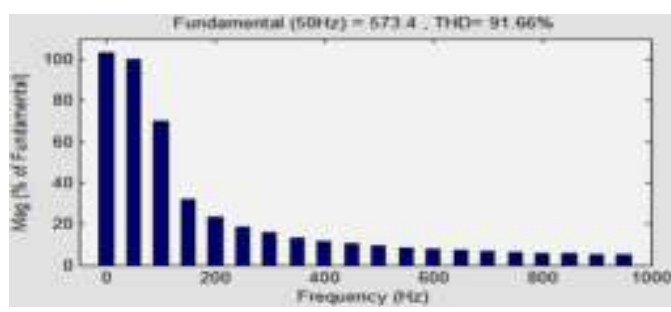

Fig. 9 Total harmonic distortion during voltage interruption

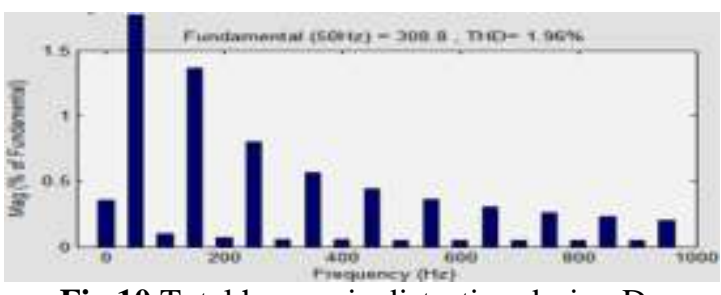

Fig.10 Total harmonic distortion during DSTATCOM operation

Above Fig.8, 9, 10 show that the factor total harmonic distortion also affects during voltage sag. During D-STATCOM operation it clearly indicates that THD also improves.

Table 3: Comparison table

\begin{tabular}{|l|l|l|l|}
\hline Position & $\begin{array}{l}\text { THD } \\
(\%)\end{array}$ & $\begin{array}{l}\text { Voltage } \\
\text { regulation (\%) }\end{array}$ & $\begin{array}{l}\text { Power } \\
\text { factor }\end{array}$ \\
\hline $\begin{array}{l}\text { Without } \\
\text { fault }\end{array}$ & 0 & 3.83 & 0.4 \\
\hline With fault & 91.66 & 100 & 0 \\
\hline $\begin{array}{l}\text { With D- } \\
\text { STATCOM }\end{array}$ & 1.96 & 8.33 & 0.7 \\
\hline
\end{tabular}




\section{CONCLUSION}

From the responses of simulation results it is observed that the single phase D-STATCOM is adequate to mitigate voltage interruption as well as improving power quality of system efficiently. In small utilities also if harmonics disturbs the whole system and reduce the power factor then this method will be useful. Large scale use of FACTS devices is an assured scenario.

Lastly, D-STATCOM demonstrates the excellent performance and will be an important feature in household system and other single phase utilities in mitigating power quality problems in the near future.

\section{REFERENCES}

[1]. Yao $\mathrm{Xu}$, Fangxing Li, "Adaptive PI control of STATCOM for voltage regulation", IEEE transactions on power delivery, vol 29, no 3, pp. 1002-1011, June 2014.

[2]. Ganesh Barve, "Application study of FACTS devices in Indian power system", International journal of computing \& technology, volume 1 , issue 1, pp 57-59, February 2014.

[3]. S.B. Aruna, "Power flow control by using optimal location of STATCOM", Publications of problems \& application in engineering research paper, volume 04, special issue 01, pp. 305-310, 2013.

[4]. Woei-Luen Chen, Wei-Gang Liang, HrongSheng Gau, "Design of a mode decoupling STATCOM for voltage control of wind driven induction generator system", IEEE transactions on power delivery. Volume 25 , no.3, pp. 17581767, July 2012.

[5]. Rupal Singh, Dushyant Kumar Singh, "Simulation of D-STATCOM for voltage fluctuation", IEEE, pp. 225-230, 2012.

[6]. Hirak K. Shah, P.N. Kapil, M.T. Shah "Simulation \& analysis of distribution static compensator",Second international conference on advanced computing and communication technologies, IEEE, pp. 1-4, 2011.

[7]. Irinjila Kranti Kiran, Jaya Laxmi,"Shunt versus series compensation in the improvement of power system performance", International journal of applied engineering research, Dindigul, volume 02, no 1, pp. 28-37, 2011.

[8]. Henri Masdi, Norman Mariun, Senan Mahmud, Azah Mohamed, Sallehhudin Yusuf "Design of a prototype of D-STATCOM for voltage sag mitigation", National power and energy conference proceedings, IEEE, pp. 61-66, 2004.

[9]. P. Rao, M.L. Crow and Z. Yang, "STATCOM control for power system voltage control applications", IEEE transactions power delivery, vol 15, no 4, pp. 1311-1317, Oct 2000.
[10]. K.R.Pandiyar,"FACTS controllers in power transmission and distribution", New age International Ltd., pp. 173-175, 2007.

[11]. Narain G. Hingorani, Laszlo Gyugyi, "Understanding FACTS, concepts and technology of flexible AC transmission systems", New York IEEE press, pp. 16-19, 2000 . 